\title{
IDENTIFICATION OF THE MICROBIOLOGICAL RISKS OF CONTAMINATION OF CATTLE AND PIG CARCASSES WITH PATHOGENS AT SLAUGHTER AND PROCESSING
}

\author{
ИДЕНТИФИКАЦИЯ МИКРОБИОЛОГИЧЕСКИХ РИСКОВ \\ КОНТАМИНАЦИИ ТУШ КРУПНОГО РОГАТОГО СКОТА \\ И СВИНЕЙ ПАТОГЕННЫМИ МИКРООРГАНИЗМАМИ \\ ПРИ УБОЕ И ПЕРЕРАБОТКЕ
}

\author{
Bataeva D.S., Yushina Yu.K., Zaiko E.V. \\ The V.M. Gorbatov All-Russian Meat Research Institute, Moscow, Russia
}

\begin{abstract}
Ключевые слова: микробиологические риски, убой и переработка крупного рогатого скота и свиней, контаминация поверхности туш, микроорганизмы рода Salmonella, Listeria, Listeria monocytogenеs, санитарные стандартные операционные процедуры.
\end{abstract}

\section{Аннотаиия}

В данной статье определяются риски контаминации патогенными микроорганизмами туш крупного рогатого скота и свиней на различных этапах их убоя и переработки. Для установления критических точек проведень исследования мяса (в тушах, полутушах и отрубах) и мясных полубабрикатов из говядины и свинины на наличие микроорганизмов рода Salmonella, Listeria и бактерий вида Listeria monocytogenes в образиах, отобранных деструктивными (из глубинь) и недеструктивными (с поверхности) методами. Установлено, что глубокие слои мясных отрубов из говядины и свинины не обсеменены микроорганизмами рода Salmonella и бактериями вида L.monocytogenes. Однако выявлена контаминация поверхности туш и полутуш крупного рогатого скота и свиней бактериями рода Salmonella u L.monocytogenes на этапах съемки шкур и извлечения из туш внутренних органов. Сухой и мокрый туалет туш и полутуш не способствует снижению их обсеменённости. Данный факт является причиной контаминаиии мясных полуфабрикатов (мелкокусковых и фаршевых), что было установлено при исследовании.
\end{abstract}

\section{Введение}

Сегодня в России, в условиях экономических санкций и импортозамещения, происходит стимулирование роста производства основных видов сельскохозяйственной продукции и пищевых продуктов. В связи с этим, одной из главных задач является обеспечение качества и безопасности выпускаемого продовольствия, оценка его стабильности, в том числе и в микробиологическом плане, на всех этапах производства.

Многие возбудители пищевые инфекций, широко распространенные в природе - в почве, воде, животных и растениях, попадают на перерабатывающие предприятия вместе с сырьем. Некоторые из них способны выживать в течение длительного времени. Например, Listeria spp. выживают от 24 ч до нескольких месяцев, микроорганизмы рода Salmonella от 6 ч до 4,0 лет $[1,2]$.

Неудовлетворительные условия получения, первичной обработки и хранения сырья становятся основной причиной интенсивного накопления ши-
Keywords: microbiological risks, slaughter and processing of cattle and pigs, contamination of carcass surfaces, microorganisms of the genera Salmonella and Listeria, Listeria monocytogenes, sanitation standard operating procedures.

\section{Abstract}

In this work, the risk of contamination of cattle and pig carcasses with pathogens at different stages of their slaughter and processing was assessed. The analysis of meat (carcasses, half carcasses and cuts) and meat semi-prepared products from beef and pork for the presence of the microorganisms of the genera Salmonella and Listeria, and Listeria monocytogenes in the samples taken by the destructive (from the depth) and nondestructive (from the surface) methods was carried out to determine the critical points. It was found that the deep layers of beef and pork cuts were not contaminated with the microorganisms of the genus Salmonella and L.monocytogenes. However, surface contamination of cattle and pig carcasses and half-carcasses with Salmonella and L.monocytogenes was revealed at the stages of hide removal and evisceration of the carcasses. Dry and wet cleaning of carcasses and half-carcasses did not facilitate the reduction of contamination. This fact is the cause of contamination of meat semi-prepared products (small-sized and minced), which was established during the study.

\section{Introduction}

Nowadays, in Russia, in the conditions of the economic sanctions and import substitution, the stimulation of the growth in production of the main types of agricultural and food products can be seen. In this connection, one of the main tasks is assurance of quality and safety of manufactured food products, and assessment of their stability, in particular, from the microbiological point of view, at all stages of production.

Many causative agents of food infections, which are ubiquitous in the environment (in soil, water, animals and plants), enter processing plants with raw material. Some of them are capable of surviving during the long period of time. For example, Listeria spp. survive from 24 hours to several months, the microorganisms of the genus Salmonella from 6 hours to 4.0 years $[1,2]$.

Unsatisfactory conditions of production, primary processing and storage of raw material are becoming the main reason for intensive accumulation of a wide range of conditionally pathogenic and pathogenic microflora, 
рокого спектра условно-патогенной и патогенной микрофлоры, на фоне которого возможно присутствие наиболее опасных возбудителей пищевых инфекций, в том числе сальмонелл, L.monocytogenes и др.

В мясе максимальная микробиологическая нагрузка обычно приходится на его поверхность, а в глубоких слоях она невелика или вообще отсутствует. Однако, при производстве мелкокусковых полуфабрикатов, поверхностная микрофлора мяса может распределяться по всему объему продукта.

В свою очередь, отклонение от традиционной технологии и внедрение новых, порой недостаточно изученных способов обработки сырья, упаковки и хранения продуктов и полуфабрикатов являются не менее важными факторами риска размножения различных патогенов [3].

Контаминация поверхности туш микроорганизмами происходит при убое и переработке животных. Например, в момент отрыва шкуры от туши воздух убойно-разделочного цеха наполняется пылью и грязью, а, соответственно, и микроорганизмами, которые впоследствии осаждаются на поверхности туш [4].

Известно, что на $1 \mathrm{~cm}^{2}$ волосяного покрова крупного рогатого скота содержится до 7,0 $10^{8}$ микроорганизмов, свиней - до 6,0 $10^{8} \mathrm{KOЕ}$. С поверхности кожного покрова свиней были выделены сальмонеллы в $26 \%$ случаев, E.coli - 60\%, споровые гнилостные бактерии - 100 \% случаев. Наибольшая степень микробного обсеменения кожного покрова животных отмечается осенью и весной [5].

Обсеменение внутренней поверхности туш может происходить в процессе извлечения внутренних органов при нарушении целостности желудочно-кишечного тракта и при неправильной выемке прямой кишки (проходника).

Перенос микроорганизмов с загрязненных участков поверхности туш (ахилловы сухожилия, брюшная стенка, грудина) на те, где их до этой технологической операции не выявляли (боковая, грудная стенка) наблюдается при зачистке туш, особенно с применением воды.

С поверхности в глубокие слои мяса бактерии проникают с разной скоростью, которая зависит от влажности, температуры, наличия и целостности корочки подсыхания на туше и др. Например, микроорганизмы рода Salmonella могут проникать на глубину 14 см за 24 ч при комнатной температуре, но при температуре $2-4{ }^{\circ} \mathrm{C}$ интенсивность проникновения резко снижается и составляет не более 1 см в течение месяца [6].

Дальнейшая переработка контаминированного патогенами мясного сырья в зависимости от условий его переработки чревато попаданием возбудителя в готовые продукты, обуславливая высокую степень риска для потребителя.

Целью нашей работы являлась идентификация микробиологических рисков контаминации туш крупного рогатого скота и свиней патогенными микроорганизмами на этапах убоя и переработки крупного рогатого скота и свиней. on which background the presence of the most hazardous causative agents of food infections, including Salmonella, L.monocytogenes and others, is possible.

In meat, the maximum microbiological load usually falls on its surface, while in the deep layers it is low or absent. However, upon production of small-sized semi-prepared products, surface microflora of meat can be distributed throughout a product volume.

In turn, a deviation from the traditional technology and introduction of new, sometimes insufficiently studied methods of raw material processing, packaging and storage of products and semi-prepared products is an equally important risk factor of proliferation of different pathogens [3].

Contamination of carcass surfaces with microorganisms happens during animal slaughter and processing. For example, at the moment of hide separation from a carcass, the air in the slaughter and dressing shop is filling with dust and dirt, and consequently, with microorganisms, which then settle on carcass surfaces [4].

It is known that $1 \mathrm{~cm}^{2}$ of cattle hair contains up to $7.0 \cdot 10^{8}$ microorganisms, pig hair up to $6,0 \cdot 10^{8} \mathrm{CFU}$. On the skin of pigs, Salmonella was detected in $26 \%$, E.coli in $60 \%$ and sporeforming spoilage bacteria in $100 \%$ of cases. The highest degree of microbial contamination of animal skin was observed in autumn and summer [5].

Contamination of the internal carcass surface can occur during the process of evisceration upon damage of the integrity of the gastrointestinal tract and improper removal of back gut.

Carryover of microorganisms from the contaminated areas of carcass surfaces (Achilles tendon, abdomen wall, sternum) to the surfaces, where contamination was not revealed until this technological operation (side, chest wall), is observed during carcass cleaning especially when using water.

Bacteria penetrate from a surface to the deep layers of meat with different speed, which depends on moisture, temperature, presence and integrity of a dry crust on a carcass and so on. For example, microorganisms of the genus Salmonella can penetrate to the depth of $14 \mathrm{~cm}$ for 24 hours at room temperature, but at a temperature of $2-4^{\circ} \mathrm{C}$ the intensity of penetration sharply decreases and is not more than $1 \mathrm{~cm}$ a month [6].

Further processing of meat raw material contaminated with pathogens depending on the conditions of its processing is fraught with contamination of finished products leading to the high degree of risks for consumers.

The aim of our work was to identify the microbiological risks of cattle and pig carcass contamination with pathogens at the stages of cattle and pig slaughter and processing.

To achieve the stated goal, the following tasks were set:

1. Monitoring of surfaces of cattle and pig carcasses at different stages of animal slaughter and processing, as well as meat and semi-prepared products from beef and pork for the presence of the microorganisms of the genera Salmonella and Listeria, and L.monocytogenes.

2. Analysis and identification of the risks of contamination of cattle and pig carcasses with the micro- 
Для достижения поставленной цели были определены следующие задачи:

1. Проведение мониторинга поверхности туш крупного рогатого скота и свиней на различных этапах убоя и переработки животных, а также мяса и мясных полуфабрикатов из говядины и свинины на наличие микроорганизмов рода Salmonella, Listeria и бактерий вида L.monocytogenes.

2. Анализ и идентификация рисков контаминации туш крупного рогатого скота и свиней микроорганизмами рода Salmonella, Listeria и бактериями вида L.monocytogenes.

\section{Материалы и методы}

Объектами исследования являлись говядина, полученная от 5 групп животных и свинина, полученная от 1 группы в тушах, полутушах и отрубах; полуфабрикаты мясные: мелкокусковые и рубленые. В каждой группе исследованы туши от 5 животных.

Отбор, подготовку проб и микробиологические исследования проводили в соответствии с ГОСT ISO 7218-2011 [7]; ГОСТ 31904-2012 [8]. Отбор проб (смывов) с туш, полутуш крупного рогатого скота (далее КРС) и свиней проводили согласно ГОСТ Р ИСО 17604 [9]. Для обеспечения представительности проб, наиболее полно и достоверно характеризующих микробное загрязнение туш, смывы были отобраны с большего числа туш, а не с большего количества зон одной туши.

Пробы отбирали на следующих точках убоя и переработки животных:

- после полировочной машины (убой свиней);

- после съемки шкуры (убой крупного рогатого скота);

- после извлечения внутренних органов;

- финальной точке, но не позднее 12 ч после убоя.

Отбор проб проводили не деструктивным методом с помощью губки.

На тушах и полутушах определяли зону отбора проб. Затем открывали пакет, содержащий стерильную губку, и добавляли определенный объем пептонно-солевого раствора, необходимого для ее смачивания. Губку с внешней стороны пакета разминали до полного ее смачивания. Надевали стерильные перчатки и осторожно извлекали губку из пакета. Помещали рамку-трафарет на выбранную зону, протирали губкой ограниченную рамкой площадь $(10 \times 10$ см $)$ приблизительно 10 раз в вертикальном и 10 раз в горизонтальном направлениях.

После указанной процедуры губку помещали обратно в пакет и добавляли оставшийся водно-солевой раствор.

Отбор проб от мясных отрубов проводили из глубоких слоев после обжига его поверхности согласно ГОСТ Р ИСО 6887-2 [10] и ГОСТ Р 54354 [11], а от мелкокусковых полуфабрикатов и фаршей отбор проводился без обжига.

Микробиологические исследования проб и смывов на наличие микроорганизмов рода Salmonella и вида L.monocytogenes проводили согласно ГОСТ Р 54354, ГОСТ 32031 [12], ГОСТ 31659 [13]. organisms of the genera Salmonella and Listeria, and L.monocytogenes.

\section{Materials and methods}

The subjects of research were beef from five groups of animals and pork from one group in carcasses, half-carcasses and cuts; meat semi-prepared products (small-sized and minced). In each group, carcasses of five animals were investigated.

Sampling, sample preparation and microbiological investigations were carried out according to GOST ISO 7218-2011 [7] and GOST 31904-2012 [8]. Sampling (taking swabs) from carcasses, half-carcasses from cattle and pigs was carried out according to GOST R ISO 17604 [9]. To ensue sampling representativeness for more complete and reliable characterization of microbial contamination of carcasses, swabs were taken from more carcasses and not from more sampling areas on one carcass.

Samples were taken at the following points of animal slaughter and processing:

- after polishing machine (slaughter of pigs);

- after hide removal (cattle slaughter)

- after evisceration;

- final point, but not later than 12 hours after slaughter.

Sampling was carried out by the nondestructive method using a sponge.

An area of sampling was specified on carcasses and half-carcasses. Then, a bag containing a sterile sponge was opened, a specified volume of the peptone saline solution necessary for its moistening was added. The sponge was massaged from the external bag surface until its full moistening. Sterile gloves were put on and the sponge was carefully taken from a bag. The sampling template was placed on the chosen area. The sponge was wiped over the sampling area $(10 \mathrm{~cm} \times 10 \mathrm{~cm})$ restricted with the sampling template approximately 10 times in the vertical and 10 times in the horizontal directions.

After the above mentioned procedure, the sponge was put back into a bag and the remaining saline solution was added.

Sampling from meat cuts was carried out from the deep layers after flaming it surfaces according to GOST R ISO 6887-2 [10] and GOST R 54354 [11]; sampling from smallsized semi-prepared products and minced meat was carried out without flaming.

Microbiological investigations of the samples and swabs for the presence of the microorganisms of the genus Salmonella and L.monocytogenes was carried out according to GOST R 54354, GOST 32031 [12] and GOST 31659 [13].

\section{Results and discussion}

When assessing the cuts and semi-prepared products from beef and pork for the presence of the microorganisms of the genus Salmonella and L.monocytogenes, the results presented in Figure 1 were obtained.

It can be seen from Fig. 1 that the pathogens were not revealed in the meat cuts. However, small-sized semi-prepared products and minced meat from beef and pork were contaminated with the pathogenic microorganisms: Salmonella (13 and $11 \%$ ) and L.monocytogenes (33 and 27\%). 


\section{Результаты и их обсуждение}

При оценке отрубов и полуфабрикатов из говядины и свинины на наличие микроорганизмов рода Salmonella и бактерий L.monocytogenes были получены результаты, представленные на рисунке 1.

Из рисунка 1 видно, что в мясных отрубах патогенные микроорганизмы не выявлены. Однако мелкокусковые полуфабрикаты и фарши из говядины и свинины контаминированы патогенными микроорганизмами: сальмонеллами 13 и $11 \%$, a L.monocytogenes 33 и $27 \%$ соответственно.

Причина в получении таких результатов заключатся в том, что используются разные подходы к подготовке проб мясных отрубов и мелкокусковых, а также рубленых полуфабрикатов для микробиологических исследований.

Согласно действующей нормативной документации, отбор проб от мясных отрубов, а также от мяса в тушах, полутушах, четвертинах, крупнокусковых полуфабрикатов проводится из глубоких слоев, т.е. после стерилизации поверхности путем ее обжига и удаления этого участка. Нормативы на микробиологические показатели, указанные в Единых требованиях (ET), в Технических Регламентах Таможенного Союза (ТР ТС), приведены для оценки глубоких слоев.

Таким образом, при анализе отрубов, а также мяса в тушах, полутушах, четвертинах, крупнокусковых полуфабрикатов производится оценка только глубоких слоев, а контаминация поверхности патогенными микроорганизмами не учитывается.

Однако при исследовании мелкокусковых и рубленых полуфабрикатов определен другой способ пробоподготовки - без обжига поверхности. Соответственно и нормативные значения микробиологических показателей оценивают поверхностные и глубокие слои суммарно.

Наиболее критичными с точки зрения контаминации туш КРС являются съемка шкур, извлечение внутренних органов, сухая и мокрая зачистка полутуш, а при убое свиней - съемка шкур, а если первичная переработка осуществляется без съемки шкуры, то шпарка, извлечение внутренних органов, сухая и мокрая зачистка полутуш. Исходя из вышесказанного, нами был проведен мониторинг на наличие микроорганизмов рода Salmonella, Listeria, а также бактерий L.monocytogenes туш крупного рогатого скота (далее КРС) и свиней на различных этапах их убоя и переработки.

Результаты исследований представлены на рисунках 2-5.

Исследованиями установлено (рисунок 2), что уровень контаминации патогенными микроорганизмами поверхности туш КРС после съемки шкуры у всех групп животных существенно отличается. Различие наблюдается не только в уровне контаминации, но и в выявляемых микроорганизмах. Так на поверхности туш КРС в четырех группах из пяти были выявлены Listeria spp., что составляет $80 \%$ от всего количества исследованных туш. Таким образом, можно предположить, что кожный покров КРС является одним из основных источником контаминации туш микроорганизмами рода Listeria. При этом уровень контамина-
The reason of obtaining such results resides in the fact that different approaches are used for preparation of samples from meat cuts and small-sized as well as minced semi-prepared products for the microbiological analysis.

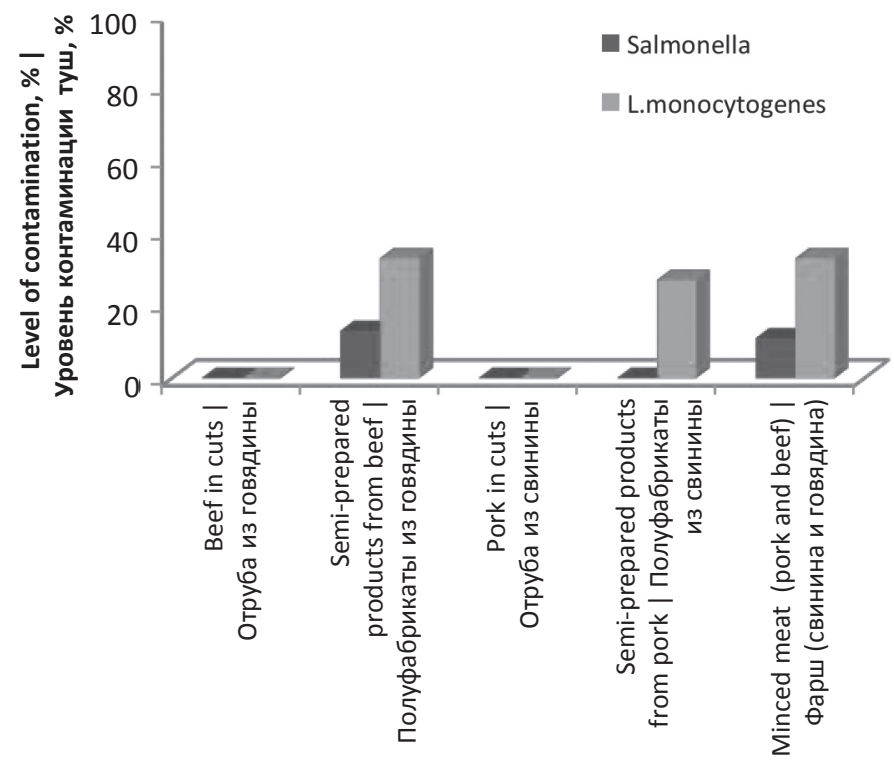

Figure 1. Results of the investigation of meat cuts, small-sized semiprepared products and minced meat for the presence of the pathogenic microorganisms

Рис. 1. Результаты исследования мясных отрубов, мелкокусковых полуфабрикатов и фаршей на наличие патогенных микроорганизмов

According to the current normative documentation, sampling from meat cuts and from meat in carcasses, halfcarcasses, quarters and large-sized semi-prepared products has been carried out from the deep layers; that is, after sterilization of a surface by its flaming and removing of this area. The norms for the microbiological indicators stated in the Unified Requirements, in the Technical Regulations of the Customs Union (TR CU) are given for assessment of the deep levels.

Therefore, when analyzing cuts as well as meat in carcasses, half-carcasses, quarters, large-sized semi-prepared products, an assessment of only deep layers is performed, while contamination of a surface with the pathogenic microorganisms is not taken into account.

However, when analyzing small-sized and minced semi-prepared products another method of sample preparation is established - without surface flaming. Respectively, the normative values of the microbiological indicators assess both surface and deep layers in total.

The most critical in terms of contamination of cattle carcasses are hide removal, evisceration, dry and wet cleaning of half-carcasses. When slaughtering pigs, the most critical is hide removal; and when primary processing is performed without hide removal, the most critical are scalding, evisceration, dry and wet cleaning of half-carcasses. Based on the above said, we monitored the cattle and pig carcasses for the presence of the microorganisms of the genera Salmonella and Listeria, and L.monocytogenes at different stages of their slaughter and processing.

The results of the investigation are presented in Figure 2-5.

It was established in the course of the study (Figure 2) that the level of contamination of the cattle carcass 
ции поверхности туш листериями в четырех группах животных (группах 1, 2, 4, 5) составил от 20 до $80 \%$. В тоже время, L.monocytogenes были обнаружены только на поверхности туш одной из пяти исследованных групп, что составило $20 \%$ от всего количества исследованных туш. Уровень контаминации туш 1 группы животных составил $20 \%$.

Обсеменённость поверхности туш КРС микроорганизмами рода Salmonella на этапе съемки шкуры была установлена у двух из пяти исследованных групп, что составляет $40 \%$ от всего количества исследованных туш. Уровень контаминации 1 и 3 группы составил от 20 до $40 \%$.

Из данных, представленных на рисунке 3, видно, что внутренняя поверхность 80 \% исследованных туш была обсеменена микроорганизмами рода Listeria, не относящимися к патогенным видам. Уровень контаминации между группами исследованных туш варьировал от 20 до $90 \%$.

В тоже время контаминация бактериями рода Salmonella составила $20 \%$.

Следует отметить, что у животных 2 группы на внутренней поверхности микроорганизмы рода Listeria и бактерии рода Salmonella не обнаружены.

Уровень контаминации патогенными микроорганизмами поверхности полутуш КРС после сухой и мокрой зачистки у всех групп животных (рисунок 4), как и на предыдущих этапах исследования, различен. Так на поверхности полутуш всех групп исследованных животных установлено наличие Listeria. Уровень контаминации составлял 20-90\%. В тоже время бактерии L.monocytogenes не были выявлены.

Такие результаты исследований могут свидетельствовать о том, что сухая и мокрая зачистка полутуш, которую проводят после распиловки туш, не способствует их деконтаминации.

Анализируя полутуши КРС на наличие бактерий рода Salmonella, установлена контаминация от 10 до $20 \%$ от всех исследованных образцов.

Результаты исследования поверхности туш и полутуш свиней после полировочной машины, извлечения внутренних органов, сухой и мокрой зачистки, представленные на рисунке 5, демонстрируют контаминацию Listeria поверхности 40-100\% туш, а после извлечения внутренних органов еще и контаминацию внутренней поверхности $20 \%$ туш L.monocytogenes. Бактерии рода Salmonella не были выявлены.

Полученные результаты исследований позволяют установить в качестве критических точек при убое и переработке животных следующие этапы: съемка шкур (убой КРС), шпарка (убой свиней) и извлечение внутренних органов. Мониторинг туш на этих точках переработки животных позволит получить мясо высокого санитарного уровня.

Проведенный нами мониторинг поверхности туш и полутуш крупного рогатого скота и свиней на различных этапах убоя и переработки животных, а также мясных отрубов и полуфабрикатов из говядины и свинины на наличие микроорганизмов рода Salmonella, Listeria и бактерий вида L.monocytogenes позволил проанализировать и идентифицировать риски контаминации.

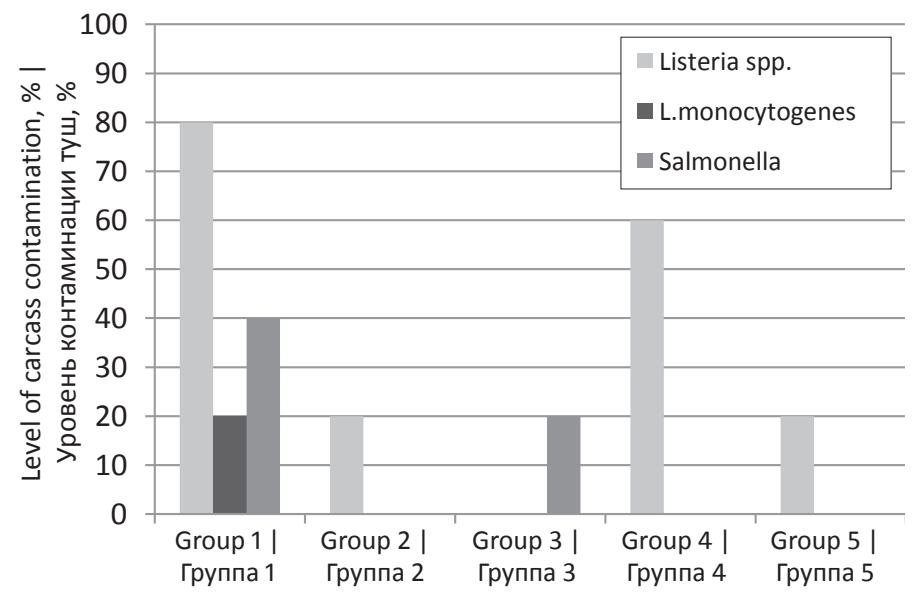

Figure 2. The level of contamination of cattle carcasses (groups 1-5) with the pathogenic microorganisms after hide removal

Рис. 2. Уровень контаминации патогенными микроорганизмами туш КРС (1-5 групп животных) после съемки шкуры

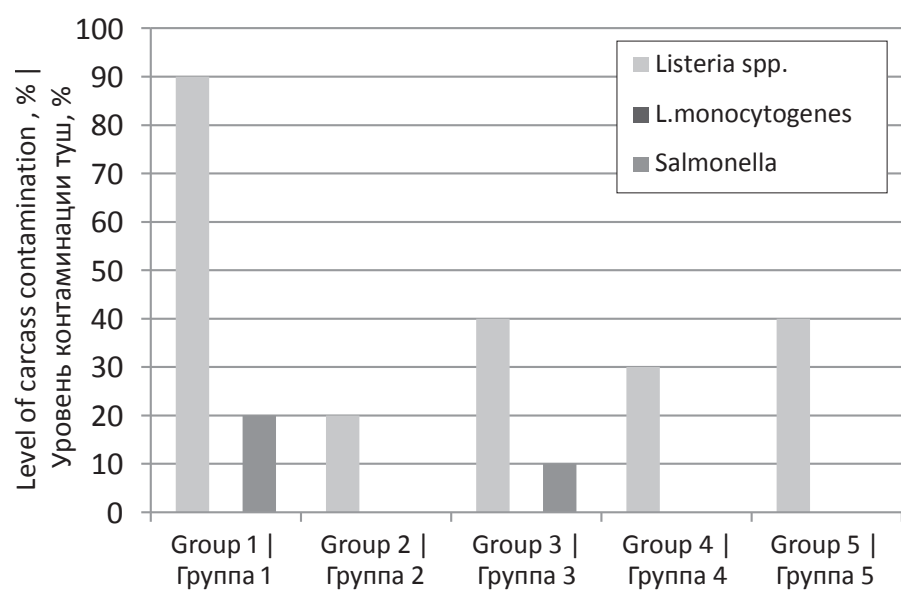

Figure 4. The level of contamination of cattle half-carcasses (animal groups 1-5) with the pathogenic microorganisms after dry and wet cleaning

Рис. 4. Уровень контаминации патогенными микроорганизмами полутуш КРС (1-5 групп животных) после сухой и мокрой зачистки

surfaces with the pathogenic microorganisms after hide removal was significantly different between all animal groups. The difference was not only in the level of contamination but also in the isolated microorganisms. For instance, Listeria spp., were detected on the surfaces of cattle carcasses in four of five groups, which accounted for $80 \%$ of the total number of the examined carcasses. Therefore, it can be concluded that cattle skin is one of the main sources of carcass contamination with the microorganisms of the genus Listeria. With that, the level of contamination of the carcass surfaces with Listeria in four animal groups (groups 1,2, 4, 5) ranged from 20 to $80 \%$. At the same time, L. monocytogenes was detected on the carcass surfaces in one of five groups, which accounted for $20 \%$ of the total number of the examined carcasses. The level of contamination of the animals from group 1 was $20 \%$.

Contamination of the cattle carcass surfaces with the microorganisms of the genus Salmonella at the step of hide removal was revealed in two of five examined groups, which was $40 \%$ of the total number of the examined carcasses. The level of contamination in groups 1 and 3 was in a range of 20 to $40 \%$. 


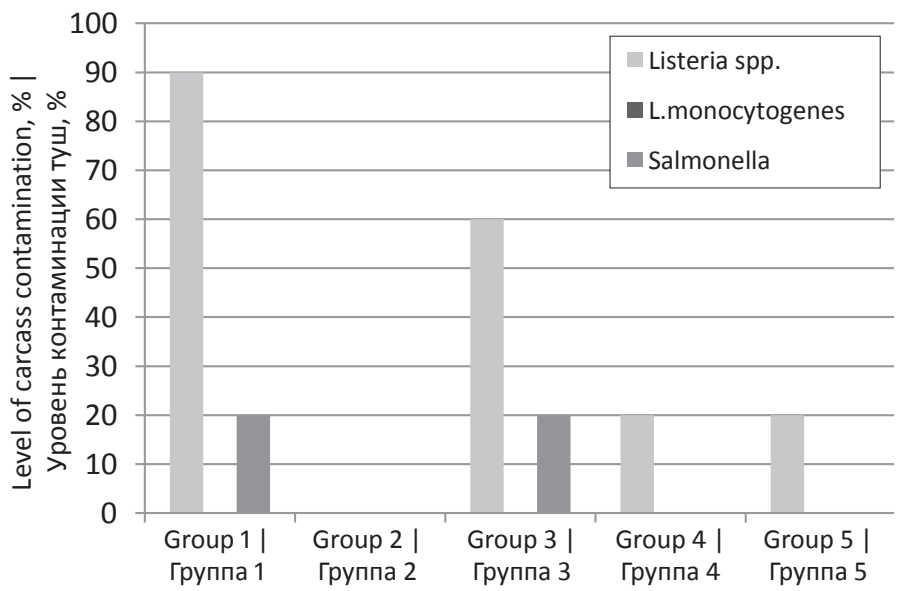

Figure 3. The level of contamination of cattle carcasses (groups 1-5) with the pathogenic microorganisms after evisceration

Рис. 3. Уровень контаминации патогенными микроорганизмами туш КРС (1-5 групп животных) после извлечения внутренних органов

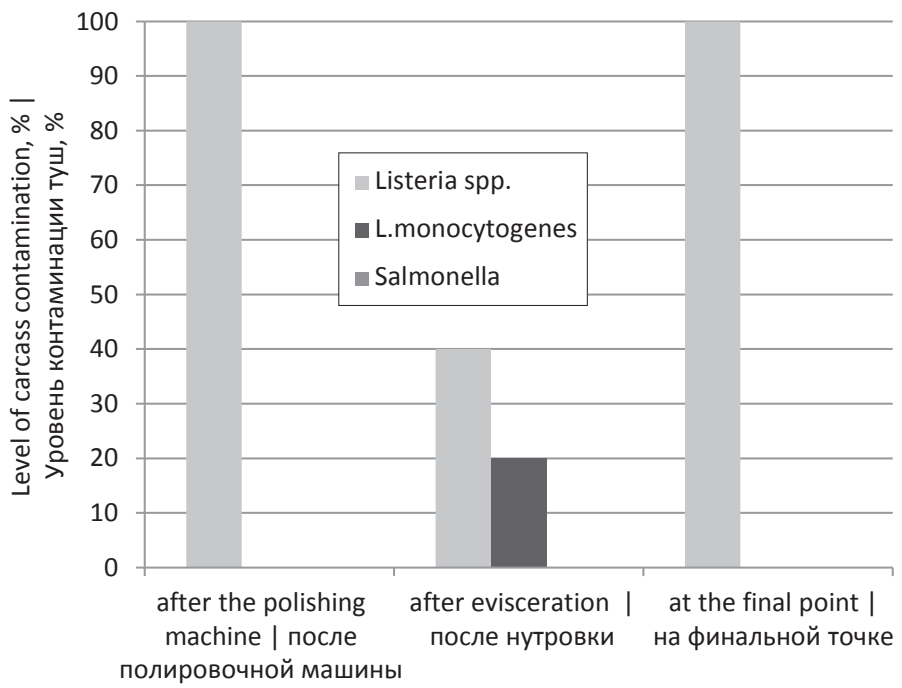

Figure 5. The level of contamination of pork carcasses with the pathogenic microorganisms at different stages of animal slaughter and processing

Рис. 5. Уровень контаминации патогенными микроорганизмами туш свиней на различных этапах убоя и переработки животных

Установлено, что:

Глубокие слои мясных отрубов из говядины и свинины были свободны от микроорганизмов рода Salmonella, Listeria и бактерий вида L.monocytogenes при условии предварительного обжига поверхности образца и удалении обожжённого участка.

В полуфабрикатах из говядины и свинины, исследуемые микроорганизмы выявляются.

В 13 \% исследованных мелкокусковых полуфабрикатах из говядины были обнаружены микроорганизмы рода Salmonella и бактерии вида L.monocytogenes в $33 \%$ образцов. В то же время, в полуфабрикатах из свинины микроорганизмы рода Salmonella отсутствовали, a L.monocytogenes выявили в 27 \% образцов. В фаршах, составленных из говядины и свинины, уровень контаминации бактериями рода Salmonella достигал $11 \%$, a L.monocytogenes 33 \% исследованных образцов.

Критическими точками при производстве говядины и свинины являются съемка шкуры и извлечение внутренних органов. Это установлено на основании
The data presented in Figure 3 show that the internal surfaces of $80 \%$ of the examined carcasses were contaminated with the microorganisms of the genus Listeria that did not belong to the pathogenic species. The level of contamination varied between groups of the examined carcasses from $20 \%$ to $90 \%$.

At the same time, contamination with the bacteria of the genus Salmonella was $20 \%$.

It is necessary to note that in animals of group 2, Listeria and Salmonella were not detected.

Similar to the previous stages of the study, the level of contamination of the cattle carcass surfaces after dry and wet cleaning in all groups of animals (Figure 4) was different. For example, the presence of Listeria was found on the surfaces of half-carcasses in all groups of the examined animals. The level of contamination was $20-90 \%$. At the same time, L.monocytogenes was not detected.

These results of the investigation suggest that dry and wet cleaning of half-carcasses, which is carried out after carcass splitting, does not facilitate decontamination.

By analyzing the cattle half-carcasses on the presence of Salmonella, contamination in a range from 10 to $20 \%$ of all analyzed samples was established.

The results of the investigation of pork carcasses and half-carcasses after the polishing machine, evisceration, dry and wet cleaning presented in Figure 5 demonstrate surface contamination with Listeria in $40-100 \%$ of carcasses, and also contamination of the internal surface with L.monocytogenes after evisceration in $20 \%$ of carcasses. The bacteria of the genus Salmonella were not revealed.

The obtained results of the investigation allow establishing the following stages in animal slaughter and processing as the critical points: hide removal (cattle slaughter), scalding (pig slaughter) and evisceration. Monitoring of carcasses at these points of animal processing will enable production of meat with high sanitary level.

The performed monitoring of surfaces of cattle and pig carcasses and half-carcasses at different stages of animal slaughter and processing, as well as the meat cuts and semi-prepared products from beef and pork on the presence of the microorganisms of the genera Salmonella and Listeria, and L.monocytogenes allow analysis and identification of the risks of contamination.

It was established that:

The deep levels of meat cuts from beef and pork were free from the microorganisms of the genera Salmonella and Listeria, and L.monocytogenes on condition of preliminarily flaming a sample surface and removing the burned area.

The microorganisms under investigation were revealed in the semi-prepared products from beef and pork.

The microorganisms of the genus Salmonella were found in $13 \%$ of the analyzed small-sized semi-prepared products from beef, while L. monocytogenes was isolated from $33 \%$ of the samples. At the same time, Salmonella was not detected in the semi-prepared products from pork, while L. monocytogenes was isolated from $27 \%$ of the samples. In minced meat prepared from beef and pork, the level of contamination with Salmonella and L. monocytogenes was $11 \%$ and $33 \%$ of all analyzed samples, respectively.

The critical points in beef and pork production are hide removal and evisceration. This was established by the mi- 
микробиологического анализа внешней и внутренней поверхностей туш КРС и свиней.

Поверхность 20\% туш КРС после съемки шкур контаминирована L.monocytogenes. Другими видами рода Listeria туши КРС контаминированы от 20 до $80 \%$, а свиные туши контаминированы на $100 \%$.

Внутренние поверхности 20-90\% исследованных туш крупного рогатого контаминированы непатогенными Listeria. Внутренняя поверхность 20 \% свиных туш при этом была контаминирована L.monocytogenes и 40-100\% другими видами Listeria.

После съемки шкур поверхность 20-40\% туш КРС контаминирована микроорганизмами рода Salmonella, а после извлечения внутренних органов, внутренняя поверхность контамирована у 20 \% туш. Микроорганизмов рода Salmonella на свиных тушах выявлено не было.

Сухая и влажная зачистка полутуш КРС и свиней не способствовала явному снижению их обсеменённости.

Патогенные микроорганизмы на тушах, полутушах (четвертинах) были выявлены только тогда, когда навеска отбиралась без предварительного обжига поверхности отруба. Согласно СП 3.1.7.2616-10 [14] охлажденное и замороженное мясное сырье (мясо в тушах, полутушах, четвертинах и отрубах, мясо в блоках, мясо птицы, мясо механической обвалки, субпродукты), полуфабрикаты, а также сырокопченые (сыровяленые) изделия относят к категории высокого риска контаминации бактериями рода Salmonella. Однако из этого перечня только рубленые, мелкокусковые полуфабрикаты, блоки мясные замороженные, мясо механической обвалки отбирают на выявление патогенов без обжига поверхности.

\section{Выводы}

Таким образом, на основании полученных результатов мы рекомендуем проводить отбор проб для выявления патогенов от туш, полутуш (четвертин, отрубов, крупнокусковых полуфабрикатов) без обжига поверхности, так как именно они на различных этапах убоя и переработки животных в большей степени подвержены риску обсеменения.

Частота обнаружения бактерий рода Listeria свидетельствует об интенсивной циркуляции возбудителя листериоза на мясоперерабатывающих предприятиях. Полученные результаты доказывают наличие благоприятных условий для выживания патогенных микроорганизмов при убое и первичной переработке скота и потенциальную опасность контаминации ими готовых продуктов. Поэтому на мясоперерабатывающих предприятиях необходимо в качестве показателя контроля качества санитарной обработки ввести бактерии рода Listeria, а не только L.monocytogenes, а также смывы с туш в качестве показателя безопасности этапов убоя.

БИБЛЛОГРАФИЧЕСКИЙ СПИСОК 1. Dormont D. Prions, BSE and food. International Journal of Food Microbiology. 15 September 2002; 78 (1-2): 181-189

2. Алимов М.А. Контаминированность объектов ветеринарного надзора возбудителем листериоза и биологические свойства выделенных культур. Аиссертация. 2004. 152 с.

3. Commission regulation (EC) №1688/2005 of 14 October 2005 implementing Regulation (EC) № 853/2004 of the European Parliament and of the Council as regards special guarantees crobiological analysis of the internal and external surfaces of the cattle and pig carcasses.

The surfaces of $20 \%$ of cattle carcasses after hide removal were contaminated with $L$. monocytogenes. The other species of Listeria contaminated the cattle carcasses in a range of 20 до $80 \%$; the pig carcasses were contaminated at a level of $100 \%$.

The internal surfaces of $20-90 \%$ of the examined cattle carcasses were contaminated with nonpathogenic Listeria. With that, the internal surfaces of $20 \%$ of the examined pig carcasses were contaminated with L.monocytogenes and 40-100\% with other species of Listeria.

The microorganisms of the genus Salmonella contaminated the surfaces of $20-40 \%$ of cattle carcasses after hide removal and the internal surfaces of $20 \%$ of carcasses after evisceration. Salmonella was not detected on the pork carcasses.

Dry and wet cleaning of the cattle and pig half-carcasses did not ensure the detectable reduction of their contamination.

The pathogenic microorganisms on the carcasses, halfcarcasses (quarters) were revealed only when a sample was taken without preliminary flaming a cut surface. According to SP 3.1.7.2616-10 [14], chilled and frozen meat raw materials (meat in carcasses, half-carcasses, quarters and cuts, meat in blocks, poultry meat, mechanically deboned meat, by-products), semi-prepared products, as well as uncooked smoked (raw air-dried) products fall in the category of high risk of contamination with the bacteria of the genus Salmonella. However, from this list, only minced and small-sized semi-prepared products, frozen meat blocks, mechanically deboned meat are sampled for analysis on pathogens without surface flaming.

\section{Conclusion}

Therefore, on the basis of the obtained results, we recommend to carry out sampling for detection of pathogens from carcasses, half-carcasses (quarters, cuts, large-sized semi-prepared products) without surface flaming as it is these products that are subjected to the risk of contamination at different stages of animal slaughter and processing to a greater degree.

The frequency of detection of Listeria suggests an intensive circulation of the causative agent of listeriosis in meat processing enterprises. The obtained results prove the presence of the favorable conditions for survival of the pathogenic microorganisms at cattle slaughter and processing and the potential hazard of contamination of ready products with these organisms. In meat processing plants, therefore, it is necessary to introduce detection of the bacteria of the genus Listeria and not only L.monocytogenes as indicators of sanitary treatment quality, as well as swabs from carcasses as an indicator of the safety of slaughter stages.

\section{REFERENCES}

1. Dormont D. Prions, BSE and food. International Journal of Food Microbiology. 15 September 2002; 78 (1-2): 181-189

2. Alimov M.A. Contamination of the objects of veterinary inspection with the causative agent of listeriosis and the biological properties of isolated cultures. Dissertation. 2004. 152 pages. 3. Commission regulation (EC) No 1688/2005 of 14 October 2005 implementing Regulation (EC) No 853/2004 of the European Parliament and of the Council as regards special guarantees 
concerning Salmonella for consignments to Finland and Sweeden of certain meat and eggs (Text with EEA relevance)

4. Батаева А.С., Минаев М.Ю., Краснова М.А. Аспекты санитарно-микробиологического контроля охлажденного мяса. Все о мясе. 2008;6: 48-50.

5. Хамнаева Н.И. Особенности санитарно-микробиологического контроля сырья и продуктов питания животного происхождения. Учебное пособие. 2006.

6. Костенко Ю.Г. Руководство по санитарно-микробиологическим основам и предупреждению рисков при производстве и хранению мясной продукции. 2014, 636 с.

7. ГOCT ISO 7218 Микробиология пищевых продуктов и кормов Аля животных. Общие требования и рекомендации по микробиологическим исследованиям.

8. ГОСТ 31904-2012 Продукты пищевые. Методы отбора проб Аля микробиологических испытаний.

9. ГОСТ Р ИСО 17604-2011 Микробиология пищевых проАуктов и кормов Аля животных. Отбор проб с туши Аля микробиологического анализа.

10. ГОСТ Р ИСО 6887-2-2013 Микробиология пищевых проАуктов и кормов Аля животных. Подготовка проб, исходной суспензии и десятикратных разведений Аия микробиологических исследований Часть 2 Специальные правила подготовки мяса и мясных продуктов.

11. ГОСТ Р 54354-2011 Мясо и мясные продукты. Общие требования и методы микробиологического анализа.

12. ГОСТ 32031-2012 Продукты пищевые. Методы выявления бактерий Listeria monocytogenes.

13. ГОСТ 31659 Продукты пищевые. Метод выявления бактерий рода Salmonella.

14. СП 3.1.7.2616-10 «Профимактика самьмонемеза" (постановление № 36 от 26.04.2010 г) + «Изменения и дополнения №1 к СП 3.1.7.2616-10» - СП 1.3.7.2836-11.

\section{СВЕДЕНИЯ ОБ АВТОРАХ}

Принадлежность к организации

Батаева Дагмара Султановна - кандидат технических наук, доцент, руководитель направления микробиологии, ведущий научный сотрудник лаборатории «Гигиена производства и микробиология» ФГБНУ «ВНИИМП им. В.М. Горбатова»

Адрес: 109316, г. Москва, ул. Талалихина, 26

Тел.: 8 (495) 6766011

E-mail: b.dagmara@inbox.ru

Юшина Юлия Константиновна - кандидат технических наук, руководитель лаборатории «Гигиена производства и микробиология» ФГБНУ «ВНИИМП им. В.М. Горбатова»

Адрес: 109316, г. Москва, ул. Талалихина, 26

Тел.: 8 (495) 6769126

E-mail:yshinauk@mail.ru

Зайко Елена Викторовна - старший лаборант лаборатории «Гигиена производства и микробиологии» ФГБНУ «ВНИИМП им. В.М. Горбатова»

Адрес: 109316 г. Москва, ул. Талалихина 26

Тел.: 8 (495) 6766011

E-mail: el.zaiko@yandex.ru

\section{Критерии авторства}

Ответственность за работу и предоставленные сведения несут все авторы.

Все авторы в равной степени участвовали в этой работе.

Батаева Д.С. разрабатывала научно-методические подходы к проведению работ, определяла объем исследований, анализировала полученные данные, выполняла описательную часть и корректировала после подачи в редакцию.

Зайко Е.В. отбирала объекты исследования, выполняла микробиологический анализ.

Юшина Ю.К. занималась описательной частью, анализировала полученные данные

Авторы в равных долях имеют отношение к написанию рукописи и одинаково несут ответственность за плагиат

Авторами установлены причины обсеменённости мяса.

$$
\text { Конфликт интересов }
$$

Авторы заявляют об отсутствии конфликта интересов.

Поступила 01.06.2016 concerning Salmonella for consignments to Finland and Sweden of certain meat and eggs (Text with EEA relevance)

4. Bataeva D.S., Minaev M.Yu., Krasnova M.A. Aspects of the sanitary and microbiological control of chilled meat. All about meat. 2008; 6: 48-50.

5. Khamnaeva N.I. Peculiarities of the sanitary and microbiological control of raw material and food products of animal origin Teaching Guide. 2006.

6. Kostenko Yu. G. Guideline on sanitary microbiological principals and prevention of risks upon meat product production and storage. 2014, 636 pages.

7. GOST ISO $\mathbf{7 2 1 8}$ Microbiology of foods and animal feed. General requirements and guide for microbiological research.

8. GOST 31904-2012 Food products. Methods of sampling for microbiological analyses.

9. GOST R ISO 17604-2011 Microbiology of food and animal feeding stuffs. Carcass sampling for microbiological analysis 10. GOST R ISO 6887-2-2013 Microbiology of food and animal feeding stuffs. Preparation of test samples, initial suspension and decimal dilutions for microbiological examination. Part 2 Specific rules for the preparation of meat and meat products.

11. GOST R 54354-2011 Meat and meat products. General requirements and methods of microbiological testing.

12. GOST 32031-2012 Food products. Methods for detection of Listeria monocytogenes.

13. GOST IOCT 31659 Food products. Method for the detection of Salmonella spp.

14. SP 3.1.7.2616-10 "Prevention of salmonellosis " (Resolution No 36 of 26.04.2010 r) + "Amendment No 1 to SP 3.1.7.261610" - SP 1.3.7.2836-11.

\section{AUTHOR INFORMATION}

\section{Affiliation}

Bataeva Dagmara Sultanovna - candidate of technical sciences, docent, Head of the Direction of Microbiology, leading scientific worker of the Laboratory "Hygiene of production and microbiology» of FGBNU «The V.M. Gorbatov VNIIMP»

Address: 109316, Talalikhina str., 26, Moscow, Russia

Ph.: 8 (495) 6766011

E-mail: b.dagmara@inbox.ru

Yushina Yulia Konstantinovna - candidate of technical sciences, docent, Head of the Laboratory «Hygiene of production and microbiology» of FGBNU «The V.M. Gorbatov VNIIMP»

Address: 109316, Talalikhina str., 26, Moscow, Russia

Ph.: 8 (495) 6769126

E-mail: yshinauk@mail.ru

Zaiko Elena Victorovna - senior research technician of the Laboratory «Hygiene of production and microbiology» of FGBNU «The V.M. Gorbatov VNIIMP

Address: 109316, Talalikhina str., 26, Moscow, Russia

Ph.: 8 (495) 6766011

E-mail: el.zaiko@yandex.ru

Contribution

All authors bear responsibility for the work and presented data.

All authors made an equal contribution to the work.

Bataeva D.S. developed the scientific methodical approaches to performing the work, determined the volume of investigation, analyzed the obtained data, performed the descriptive part and made corrections after submission to the editorial office.

Zaiko E.V. sampled the subjects of the investigation and performed the microbiological analysis.

Yushina Yu.K. was engaged in the descriptive part, analyzed the obtained data.

The authors were equally involved in writing the manuscript and bear the equal responsibility for plagiarism.

The authors established the causes of meat contamination.

Conflict of interest

The authors declare the absence of conflict of interest.

Received 01.06.2016 